\title{
Hvordan foreldre reagerer når barnet er overvektig
}

\section{Når ansatte i helsestasjons- og skolehelsetjenesten forteller foreldre at barnet deres er overvektig, føler mange både skam og skyld.}

\section{FORFATTERE}

Merete Waage Hanssen-Bauer

Avdelingshelsesøster

Grünerløkka familiehus, Oslo kommune

Ingrid Ruud Knutsen

Førsteamanuensis

Institutt for sykepleie og helsefremmende arbeid, Høgskolen i Oslo og Akershus

\section{SAMMENDRAG}

Bakgrunn: Nasjonale faglige retningslinjer anbefaler at helsestasjons- og skolehelsetjenesten individuelt kartlegger og veileder overvektige barn og unge.

Hensikt: Å få kunnskap om hvordan foreldre til barn på fire og åtte-ni år opplevde å få beskjed om at barnet var overvektig. Hensikten var også å finne ut hvordan foreldrene opplevde å delta i veiledningssamtaler og aktivitetstilbud.

Metode: Kvalitativ studie med individuelle intervjuer av seks mødre. Vi analyserte intervjuene ved hjelp av meningskondensering inspirert av Giorgi.

Resultat: Vi fant fellestrekk i foreldrenes opplevelser, som er sammenfattet i fire sentrale temaer: 1) opplevelse av kritikk av barnet og seg selv, 2) ønske om å beskytte barnet, 3) bekymring for barnets erfaringer, og 4) bevisstgjøring og støtte til livsstilsendring.

Konklusjon: Foreldre føler at barnets vektøkning er kritikk av barnet, men også kritikk av at de ikke har lyktes som foreldre. Å ha et barn med overvekt kan føles skamfullt. Samtaler i regi av skolehelsetjenesten gir god støtte, men for å beskytte barnet $\emptyset$ nsker ikke foreldrene at barnet er med på samtalene. Foreldre som ikke $\emptyset$ nsket å delta i aktivitetstilbud, problematiserte at barna kunne bli assosiert med det å være overvektig. De som deltok i aktivitetstilbud, fikk god støtte i å være sammen med andre i samme situasjon og fremhevet det positive ved at barn og foreldre deltok sammen i aktiviteter preget av lek og moro. 
eller lege av faglige grunner så behov for det (1). Begrunnelsene for å endre praksis var blant annet manglende dokumentasjon på effekt og nytte av høyde- og vektscreening samt bekymring for at fokusering på vekten kunne trigge spiseforstyrrelser (2).

\section{FLERE BARN OG UNGE ER OVERVEKTIGE}

Forekomsten av overvekt og fedme blant barn og unge har $\emptyset \mathrm{kt}$ de siste tiårene og beskrives i dag som en av de største utfordringene i folkehelsearbeidet (2-4). I Norge er 15 prosent av guttene og 18 prosent av jentene i alderen 4-16 år overvektige eller har fedme (2). Denne $\emptyset$ kningen plasserer Norges forekomst på nivå med Storbritannia og Norden for $\varnothing$ vrig.

\section{«Forekomsten av overvekt og fedme blant barn og unge har $\varnothing$ kt de siste tiårene.»}

Overvekt og fedme er en sammensatt utfordring (5), men en del av årsaksforklaringen er $\varnothing$ kende inaktivitet kombinert med endrete kostvaner (6). Vektøkningen forekommer i alle sosiale lag, men i grupper med lavere sosioøkonomisk status er det mer overvekt (7). Denne gruppen knyttes til lavere fysisk aktivitet og et lavere inntak av frukt og grønt $(8,9)$. På bakgrunn av vektøkningen har norske helsemyndigheter igjen valgt å innføre systematiske målinger av vekt og høyde. De anbefaler også tiltak for å forebygge og behandle overvekt og fedme $(2,6)$

\section{NYE RETNINGSLINJER}

I 2010 ga Helsedirektoratet ut «Nasjonale faglige retningslinjer for primærhelsetjenesten: Forebygging, utredning og behandling av overvekt og fedme hos barn og unge» (6). Retningslinjene beskriver aktuelle fagpersoners ansvar for helsefremmende og forebyggende tiltak, utredning og behandling. Tiltakene er delt inn i nivåer ut fra iso-KMI. KMI står for kroppsmasseindeks, som regnes ut med vekt i kilo delt på kvadratet av høyde i meter. Iso-KMI er KMI justert etter kjønn og alder (10). WHO har klassifisert vekt i fire iso-KMI-nivåer (6, s. 31). Inndelingen er vist i tabell 1.

Tabell 1: Klassifisering, tiltak og ansvar ved ulike Iso-KMI-nivåer

\begin{tabular}{llll}
\hline $\begin{array}{l}\text { Tiltaksnivå } \\
1\end{array}$ & $\begin{array}{l}\text { Klassifisering } \\
\text { Normalvekt }\end{array}$ & $\begin{array}{l}\text { Iso-KMI } \\
\text { Under } 25\end{array}$ & $\begin{array}{l}\text { Hovedtiltak } \\
\text { Systemarbeid med fokus på strukturell og individuell } \\
\text { helsefremmende og forebyggende virksomhet i kommunen. }\end{array}$ \\
3 & Overvekt & $\begin{array}{l}\text { På eller } \\
\text { over } 25\end{array}$ & $\begin{array}{l}\text { Som nivå } 1 \text { med tillegg av: Individuell kartlegging og } \\
\text { veiledning hos helses } \varnothing \text { ster. }\end{array}$ \\
3 & På eller & $\begin{array}{l}\text { Som nivå 2 med tillegg av: Tverrfaglig samarbeid og } \\
\text { onsvarsgruppe. Utredning hos fastlege. Ev. henvisning til } \\
\text { spesialist. }\end{array}$ \\
4 & Alvorlig fedme & $\begin{array}{l}\text { På eller } \\
\text { over 35 }\end{array}$ & Som nivå 3, med tillegg av: Henvisning til spesialist. \\
\hline
\end{tabular}

Iso-KMI fra 25 til 30 defineres som overvekt (6), og de faglige retningslinjene anbefaler individuell kartlegging og veiledning fra helsesøster i denne gruppen. Forskning viser at det er gunstig å sette inn tiltak så tidlig som mulig, noe som kan føre til at barnet «vokser seg ut av overvekten» (6). I 2011 ga Helsedirektoratet i tillegg ut «Nasjonale faglige retningslinjer for veiing og måling i helsestasjons- og skolehelsetjenesten», som beskriver anbefalte måletidspunkter (2). 


\section{PROSJEKT FOR Å MOTIVERE TIL LIVSSTILSENDRING}

En prosjektgruppe fra helsestasjons- og skolehelsetjenesten i en østlandskommune gjennomførte skoleåret 2011/2012 et prosjekt. Målet var at overvektige barn og deres familier skulle endre livsstil. Basert på anbefalingene for veie- og måletidspunkt i de faglige retningslinjene (2) fokuserte prosjektgruppen på barn i alderen fire og åtte-ni år (tredje klasse).

Ett årskull med tredjeklassinger fra to skoler og fireåringer fra ett årskull tilknyttet én helsesøster på helsestasjonen fikk tilbud om å delta i prosjektet. Prosjektgruppen valgte to barneskoler strategisk for å få med barn fra ulike sosiale lag. Helsesøster på helsestasjonen eller på barnets skole informerte foreldrene hvis veiing og måling av barnet viste en iso-KMI på eller over 25. Barna og foreldrene ble invitert til å delta i ett av de to følgende tilbudene:

- tilbud om tre veiledningssamtaler med helsesøster og fysioterapeut ved 0, 1 og 6 måneder etter målingen

- tilbud om tre veiledningssamtaler med helsesøster og fysioterapeut ved 0, 1 og 6 måneder etter målingen. I tillegg tilbud om å delta i en aktivitetsgruppe på kveldstid, én gang i uken over åtte uker.

I den første samtalen skulle de kartlegge barnets og familiens kostholds- og aktivitetsvaner, motivasjon til å starte en endringsprosess og hjelp til å sette mål (11). Helsesøster og fysioterapeut gjennomførte ytterligere to samtaler, der hensikten var å veilede videre ved behov.

Hvis familien takket ja til tilbud 2, forutsatte det at både barn og foreldre deltok i aktivitetsgruppene, som besto av variert lek og fysisk aktivitet. En fysioterapeut var ansvarlig for aktivitetsgruppene og gjennomførte dem i samarbeid med fysioterapistudenter. Som en del av aktivitetstilbudet var det også to gruppesamlinger med kosthold som tema. Foreldrene til ni tredjeklassinger takket ja til samtale (tilbud 1) eller samtale og aktivitetsgruppe (tilbud 2), mens ingen av foreldrene til fireåringene ønsket å delta.

\section{STUDIEN OG STUDIENS HENSIKT}

I denne studien undersøker vi hvordan foreldre opplevde å delta i prosjektet som er beskrevet over. For å få tak i foreldrenes opplevelser, tanker og erfaringer gjennomførte vi en kvalitativ studie med individuelle intervjuer (12). Vi ønsket å få kunnskap om hvordan det var for barnas foreldre å få beskjed om at barnet deres var overvektig, og hvordan det var for dem å delta i veiledningssamtaler og aktivitetstilbud. Vi søkte Norsk senter for forskningsdata (NSD) om tillatelse og fikk godkjenning til å gjennomføre studien vår.

\section{METODE}

Alle de ni foreldrene som hadde deltatt i prosjektet i regi av helsestasjons- og skolehelsetjenesten, ble spurt om å delta i intervjuunders $\varnothing$ kelsen. Seks mødre sa ja. Av de seks som ble intervjuet, var det to som deltok i tilbud 1, og fire som deltok i tilbud 2. De som ikke ønsket å delta i intervjuundersøkelsen, begrunnet det med tidspress. Vi gjennomf $\varnothing$ rte intervjuene høsten 2012.

Artikkelens førsteforfatter var leder for helsestasjonstjenesten i prosjektperioden, men hadde ikke $m \varnothing t t$ foreldrene før prosjektet. Hun var også prosjektleder og foretok de semistrukturerte intervjuene. Intervjuformen var fleksibel, slik at vi kunne stille oppfølgingsspørsmål for å få en dypere forståelse (12). Vi transkriberte intervjuene ordrett og analyserte dem med tanke på å få frem foreldrenes erfaringer. Begge forfatterne leste intervjutekstene i sin helhet, og vi samarbeidet videre i analyseprosessen for å få frem flere nyanser. Vi fulgte Giorgis metode for tekstkondensering og fant frem til sentrale temaer $i$ resultatene (13). 


\section{RESULTATER}

Et sentralt funn i denne studien er at foreldre som ble kontaktet av helsesøster på grunn av barnets overvekt, kjente på motstridende følelser. De var opptatt av å beskytte barna mot følelsen av ikke å være bra nok samtidig som de erkjente behovet for endringer for å motvirke videre utvikling av overvekt. Funnene viser fellestrekk som er sammenfattet i fire sentrale temaer: 1) opplevelse av kritikk av barnet og seg selv, 2) ønske om å beskytte barnet, 3) bekymring for barnets erfaringer, og 4) bevisstgjøring og støtte til livsstilsendring.

\section{FØLER AT BARNET OG FORELDRENE KRITISERES}

Helsesøster ringte til foreldrene og informerte om at $\varsigma \varnothing n n e n$ eller datteren hadde $\varnothing k t$ mye i vekt siden siste måling i skolehelsetjenesten. I denne studien var det kun mødre som besvarte samtalen, og deres reaksjoner varierte fra overraskelse og sinne til takknemlighet for at noen brydde seg. Noen av mødrene var alene om omsorgen, men der foreldrene bodde sammen, hadde mor diskutert henvendelsen med far. Flere ga uttrykk for at de følte seg uforberedt da helses $\varnothing$ ster ringte, og de følte seg skamfulle og hadde behov for å forsvare seg. De uttrykte at et brev i forkant av telefonsamtalen kunne forberedt dem.

Flere følte at barnets vektøkning var kritikk av barnet, men også kritikk av at de ikke hadde lyktes som foreldre:

«Men jeg syns at man blir slått akkurat der hvor man er mest sensitiv. Og det er barnet vårt, det er alltid vondt. Og vi vet liksom at vi ikke har gjort jobben vår som foreldre. Det ligger jo skam også i denne materien. Man prøver å være positive og sånn, men det ligger jo faktisk og ulmer under der.»

Flere av foreldrene i studien sa at de selv strevde med overvekt, og at det var vanskelig å hjelpe barnet med noe de ikke mestret selv:

<<Jeg syns jo egentlig det var vanskelig at nå skal jeg komme dit [til helsesøster], og så er jeg litt kraftig sjøl, og de kan tro at jeg ikke kan spise ordentlig.»

\section{ØNSKE OM Å BESKYTTE BARNET}

Alle foreldrene mente at det ikke var bra å ha for mye oppmerksomhet på vekten. De var bekymret for at barnet kunne få et negativt forhold til egen kropp og i verste fall utvikle en spiseforstyrrelse. De ønsket derfor ikke at barnet skulle være med på samtalene med helsesøster, eller at helsesøster skulle snakke alene med barnet om vektutviklingen. Det varierte hvorvidt foreldrene fortalte barnet at de deltok på samtaler i skolehelsetjenesten, eller hvorfor de deltok.

\section{«Alle foreldrene mente at det ikke var bra å ha for mye oppmerksomhet på vekten.»}

Der både barn og foreldre deltok i aktivitetstilbudet, var det flere som ville skjerme barnet og sa at det var et tilbud for alle barn. Andre foreldre takket nei til aktivitetsgrupper fordi de var redde for at barnet ville bli assosiert med «de overvektige»:

«Og i hele denne prosessen har jo han aldri skjønt hva han har vært med på. Jeg vil ikke at han skal gå rundt og tenke at han er tykk, det liker jeg ikke tanken på. Jeg syns at han skal ha et fint selvbilde, at han skal føle seg fin som han er da. Det jeg minst vil, er at han på noen som helst måte skal få vite at han er rund, eller at han er tykk eller på noen måte er noe gærent med ham, for det er det ikke.» 
Flere foreldre sa at barna så på seg selv som tykke, og at de hadde fortalt at de var lei seg for det. Noen av barna var veldig opptatt av vekt og veide seg hver dag. Flere hadde fått kommentarer fra jevnaldrende, og noen hadde blitt ertet av medelever:

«Så han så jo selv at magen hans var blitt stor, og han hadde fått kommentarer i dusjen på skolen om at ja ..., og det likte han ikke, så han var veldig lei seg for det. Og så har han begynt i fjerde klasse nå i høst, og da skal det være svømming, så han gruer seg for det, for jentene da.»

«Men han merker at når han har trening, så blir han fort svett. Og det er ubehagelig, synes han. Og han blir fortere sliten og henger litt etter andre barn, de er raskere.»

Mødrene var redde for at barnet ville føle det som kritikk hvis de satte grenser for matinntak. Særlig var det en utfordring hvis barnet var den eneste i søskenflokken som trengte restriksjoner. Flere mødre ønsket mer oppmerksomhet på sunn mat i skolens undervisning - som et tema for alle barn uavhengig av kroppsvekt. Det var for eksempel ikke så lett når andre barn hadde med seg matvarer på skolen som deres barn var blitt fortalt «ikke var lov».

\section{BEVISSTGJ $\emptyset$ RING OG ST $\varnothing$ TTE TIL LIVSSTILSENDRING}

Til tross for skam og skyldfølelse uttrykte mødrene at de ønsket informasjon om barnets vektøkning. Noen hadde ikke vært klar over at barnet hadde $\varnothing \mathrm{kt}$ så mye i vekt, og samtalene i skolehelsetjenesten hadde vært bevisstgjørende og nok til at de tok grep om situasjonen. Andre $\varnothing$ nsket tettere oppfølging og var veldig fornøyde med både aktivitetsgrupper og samtaler.

\section{«Til tross for skam og skyldfølelse uttrykte mødrene at de ønsket informasjon om barnets vektøkning.»}

Det var en ny, positiv erfaring for barnet å delta i fysisk aktivitet uten at det var konkurranse om å være best. Mødrene fikk ideer til ulike aktiviteter de kunne gjøre sammen i familien, og det bidro til forn $\varnothing y d e$ og glade barn og positive foreldre. De fikk viktig støtte i arbeidet med å endre familiens rutiner og mente det var positivt at også andre enn foreldrene informerte om fysisk aktivitet og riktig kosthold. Mødrene var klare på at barnets kosthold var deres ansvar, men at det var utfordrende:

«Det er veldig godt å sitte ved bordet og snakke om det, men hvordan skal vi få det til hjemme, og hvordan skal barna bli fornøyde med det som vi skal gjøre, uten å presse på en måte.»

\section{DISKUSJON}

Intervjuene viser at barns overvekt er et sensitivt tema for foreldrene. Flere foreldre var også uforberedte på at deres barn var i kategorien overvektig, slik også andre studier viser. Foreldre er oftere uforberedte om det er gutter enn jenter, og mer dess yngre barnet er (14-16). Studien vår viser at det var vanskelig å engasjere foreldrene til fireåringene; ingen av dem ønsket oppfølging fra helsestasjonstjenesten. Kanskje kan det henge sammen med at mange ikke tenker overvekt hos et lite barn (14) og reagerer med motstand når helsesøster påpeker barnets $\emptyset$ kende vekt.

\section{«Barns overvekt er et sensitivt tema for foreldrene.»}


En ny studie viser imidlertid at man kan predikere overvekt fra tidlig alder, og at det bør vies oppmerksomhet når små barn øker i iso-KMI (17). Foreldre opplever at det stilles spørsmålstegn ved deres foreldreferdigheter når helsepersonell påpeker overvekt. Opplevelsen forsterkes når foreldrene selv er overvektige (10), slik det også kom frem i studien vår. I tillegg føles det som kritikk av et sårbart og uskyldig barn (18). Flere av foreldrene i studien vår hadde fors $\varnothing$ kt å gå ned i vekt uten å lykkes, og de ønsket ikke at barnet skulle oppleve det samme.

Tilsvarende ser vi i en annen studie (14). Uvitende, dømmende og respekt|øs tilnærming til overvektsproblematikk kan føre til vegring mot å be om hjelp fra helsepersonell $(14,19)$. Vår studie bekrefter at overvekt er skambelagt og knyttet til normer i dagens samfunn. Det understreker at helsesøsters pålagte oppmerksomhet på barns vektutvikling krever både sensitivitet og faglig klokskap i møte med foreldrene. Helsesøster må snakke med foreldrene om barnets vekt og utvikling og finne ut hva foreldrene $\emptyset$ nsker av hjelp og veiledning. Det er viktig å ta foreldrenes opplevelse av skam og skyld på alvor når man planlegger forebyggende tiltak (20).

\section{FORELDRE HAR AMBIVALENTE FøLELSER}

I studien vår, som i andre studier $(16,18,21)$, er foreldre redde for at oppmerksomhet på vekt kan gi barnet et negativt syn på egen kropp. Å være foreldre til et barn i en stor kropp kan oppleves som en ambivalent prosess. På den ene siden vil foreldrene gjøre alt for at barna skal ha god helse uten overvekt. På den andre siden $\emptyset$ nsker de enda sterkere at barna skal ha et godt selvbilde (18). En longitudinell studie av kanadiske barn i ti-elleveårsalderen viser sammenheng mellom overvekt og risiko for å utvikle lavt selvbilde og dårlig psykisk helse senere $\mathrm{i}$ livet $(21,22)$. Barn helt ned i fire-femårsalderen er opptatt av egen kropp og hvordan de ser ut (23), og flere av barna i studien vår syntes selv de var for tykke, hadde fått kommentarer fra medelever og var blitt ertet.

\section{«Det er viktig at helsepersonell er opptatt av barnets selvfølelse og psykiske helse i tillegg til overvekten.»}

Helsesøster har en dobbeltrolle ved å være den som «varsler» foreldrene om at barnet er for tungt, og samtidig være den som veileder barn og foreldre til et godt selvbilde. I dette ligger det et dilemma. Det er viktig at helsepersonell er opptatt av barnets selvfølelse og psykiske helse i tillegg til overvekten $(16,19)$. Samtalen med foreldrene bør fokusere på muligheten for å ivareta barnets selvfølelse samtidig som det settes i gang nødvendige tiltak for å stoppe overvekten. Vi vet at det er en fordel om barnet vokser seg ut av overvekten fremfor å vente til barnet blir større og overvekten blir vanskeligere å behandle $(17,24)$.

\section{DELTOK I AKTIVITETER}

Foreldre til overvektige barn har ulike begrunnelser for å takke nei til intervensjoner mot overvekt. Blant annet er noen redde for at barnet skal bli betraktet som overvektig (16), slik det fremkom i studien vår. Dette er en utfordring det er viktig å ta på alvor slik at man ikke gjør mer skade enn gagn.

Noen $m \varnothing$ dre valgte likevel å delta i aktivitetsgruppene og opplevde støtte i å være sammen med andre med samme utfordringer. De beskrev det som en ny, positiv erfaring å være fysisk aktive sammen med egne barn og sammen med andre foreldre og barn. Barneidretten består ofte av ulike former for konkurranser i stedet for lek og moro. Tunge barn opplever ofte nederlag ved ikke å bli plukket ut på laget, eller ved å kjenne at de ikke klarer å henge med (21). Det er viktig med alternative arenaer der alle kan trives med å være fysisk aktive 
uten en prestasjonskultur.

I vår studie var det mødre som deltok i samtaler og aktivitetstilbud. De forklarte at fedrene ikke hadde anledning til å delta. En systematisk litteraturstudie viser at mor ofte har en mer aktiv rolle enn far når det gjelder familiens kosthold (25), men i vår studie kom det frem at

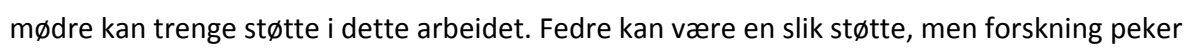
på at fedre ofte ikke anser seg som målgruppe for helsestasjonens arbeid (26). Det er et tankekors når det gjelder det helsefremmende arbeidet.

I studien vår erfarte mødrene at aktivitetstilbudet var en god st $\varnothing$ tte, og de følte seg som viktige pådrivere for aktivitet og fornøyde barn. Disse erfaringene støttes av kunnskapen om den positive sammenhengen mellom fysisk aktivitet og selvbilde (21). Andre studier viser også at intervensjoner som fokuserer på fysisk aktivitet og kosthold, kan ha positiv innvirkning på vekt og fysisk helse $(27,28)$.

Studien vår er liten, og funnene kan ikke generaliseres, men den gir likevel viktig kunnskap om foreldres erfaringer med tiltak i helsestasjons- og skolehelsetjenesten.

\section{KONKLUSJON}

Studien vår gir ny kunnskap om hvordan foreldre erfarer møtet med helsestasjons- og skolehelsetjenesten i arbeidet med å forebygge overvekt og fedme. Foreldre føler at barnets vektøkning er kritikk av barnet, men også kritikk av at de ikke har lyktes som foreldre. Å ha et barn med overvekt kan føles skamfullt. For å beskytte barnet ønsker de ikke å ha med barnet på samtaler i skolehelsetjenesten. Helsesøstre har en viktig oppgave med å formidle ny kunnskap om at overvekt i barnealder kan medføre overvekt senere, og jo tidligere man forsøker å snu en uheldig utvikling, jo bedre.

Livsstilsintervensjoner kan ha positiv innvirkning på barnets vektutvikling og helse, og helsesøster må støtte foreldrene i arbeidet med å ivareta barnets selvfølelse samtidig som de gjør endringer i aktivitetsnivå og kosthold. Studien viser at mødre kan oppleve god støtte gjennom samtaler i skolehelsetjenesten og også gjennom å delta i et aktivitetstilbud der de treffer andre i samme situasjon.

Det var positivt at tilbudet involverte både foreldre og barn, og at konkurranseprinsippene ble erstattet med lek og moro. Imidlertid er det viktig å fokusere på å få fedrene mer med. Foreldre som ikke ønsket å delta i aktivitetstilbudet, problematiserte at barna kunne bli assosiert med de overvektige. Det trengs mer forskning om hvordan livsstilsintervensjoner kan hindre overvekt og ivareta barnets selvbilde.

LES OGSÅ: Viser vektene på helsestasjonene korrekt vekt?

\section{REFERANSER}

1. Sosial- og helsedirektoratet. Kommunenes helsefremmende og forebyggende arbeid i helsestasjons- og skolehelsetjenesten: veileder til forskrift av 3. april 2003 nr. 450. Oslo: Sosial- og helsedirektoratet. 2004.

2. Helsedirektoratet. Nasjonale faglige retningslinjer for veiing og måling $i$ helsestasjons- og skolehelsetjenesten. Oslo: Helsedirektoratet. 2011.

3. Kipping RR, Jago R, Lawlor DA. Obesity in children. Part 1: Epidemiology, measurement, risk factors, and screening. BMJ 2008;337:a1824.

4. Kipping RR, Jago R, Lawlor DA. Obesity in children. Part 2: Prevention and 
management. BMJ 2008;337:a1848.

5. Elinder LS, Heinemans N, Zeebari Z, Patterson E. Longitudinal changes in health behaviours and body weight among Swedish school children - associations with age, gender and parental education - the SCIP school cohort. BMC Public Health 2014;14:640.

6. Helsedirektoratet. Nasjonale faglige retningslinjer for primærhelsetjenesten: forebygging og behandling av overvekt og fedme hos barn og unge. Oslo: Helsedirektoratet. 2010.

7. Juliusson PB, Eide GE, Roelants M, Waaler PE, Hauspie R, Bjerknes R. Overweight and obesity in Norwegian children: prevalence and socio-demographic risk factors. Acta Paediatr 2010;99(6):900-5.

8. Øvrum A. Socioeconomic status and lifestyle choices: evidence from latent class analysis. Health Economics 2011;20:971-84.

9. Øvrum A, Gustavsen G, Rickertsen K. Age and socioeconomic inequalities in health: Examining the role of lifestyle choices. Advances in Life Course Research 2014;19:1-13.

10. Juliusson PB, Roelants M, Eide GE, Moster D, Juul A, Hauspie R et al. Growth references for Norwegian children. Tidsskr Nor Laegeforen 2009;129(4):281-6.

11. Barth T, Børtveit T, Prescott P. Motiverende intervju : samtaler om endring. Oslo: Gyldendal Akademisk. 2013.

12. Kvale S, Brinkmann S, Anderssen TM, Rygge J. Det kvalitative forskningsintervju. 2. utg. Oslo: Gyldendal Akademisk. 2009.

13. Malterud K. Kvalitative metoder i medisinsk forskning: en innføring. 3. utg. Oslo: Universitetsforlaget 2011.

14. Toftemo I, Glavin K, Lagerlov P. Parents' views and experiences when their preschool child is identified as overweight: a qualitative study in primary care. Fam Pract 2013;30(6):719-23.

15. Juliusson PB, Roelants M, Markestad T, Bjerknes R. Parental perception of overweight and underweight in children and adolescents. Acta Paediatr 2011;100(2):260-5

16. Newson L, Povey R, Casson A, Grogan S. The experiences and understandings of obesity: families' decisions to attend a childhood obesity intervention. Psychol Health 2013;28(11):1287-305.

17. Glavin K, Roelants M, Strand BH, Juliusson PB, Lie KK, Helseth S et al. Important periods of weight development in childhood: a population-based longitudinal study. BMC Public Health 2014;14:160.

18. Haugstvedt KT, Graff-Iversen S, Bechensteen B, Hallberg U. Parenting an overweight or obese child: a process of ambivalence. J Child Health Care 2011;15(1):71-80.

19. Turner KM, Salisbury C, Shield JP. Parents' views and experiences of childhood obesity management in primary care: a qualitative study. Fam Pract 2012;29(4):476-81. 
20. Øen G. Forebygge overvekt hos barn og unge - et $\varnothing$ kologisk perspektiv. I: Holme H, Olavesen ES, Valla L, Hansen MB (red.). Helsestasjonstjenesten: barns psykiske helse og utvikling. Oslo: Gyldendal Akademisk. 2016. s. 481-94.

21. Danielsen YS, Stormark KM, Nordhus IH, Maehle M, Sand L, Ekornas B et al. Factors associated with low self-esteem in children with overweight. Obes Facts 2012;5(5):722-33.

22. Wang F, Wild TC, Kipp W, Kuhle S, Veugelers PJ. The influence of childhood obesity on the development of self-esteem. Health Rep 2009;20(2):21-7.

23. Goodell LS, Pierce MB, Bravo CM, Ferris AM. Parental perceptions of overweight during early childhood. Qual Health Res 2008;18(11):1548-55.

24. Lekdahl S, Holme H. Overvekt og fedme hos barn. I: Holme H, Olavesen ES, Valla L, Hansen MB (red.). Helsestasjonstjenesten: Barns psykiske helse og utvikling. Oslo: Gyldendal Akademisk. 2016. s. 241-56.

25. Savage J, Fisher J, Birch L. Parental influence on eating behavior: Conception to adolescence. Journal of Law and Medical Ethics 2007;35(1):22-34.

26. Sheriff N. Engaging and supporting fathers to promote breastfeeding: a new role for health visitors? Scandinavian Journal of Caring Sciences 2011;25:467-75.

27. Ho M, Garnett SP, Baur L, Burrows T, Stewart L, Neve M et al. Effectiveness of lifestyle interventions in child obesity: systematic review with meta-analysis. Pediatrics 2012;130(6):e1647-71.

28. Reinehr T. Lifestyle intervention in childhood obesity: changes and challenges. Nat Rev Endocrinol 2013;9(10):607-14. 